\title{
Analisis Tingkat Kemampuan Berpikir Kreatif Materi Trigonometri
}

\author{
Narita Fifi Zulaikha ${ }^{1^{*}}$, Hevy Risqi Maharani ${ }^{2}$, Mochamad Abdul Basir ${ }^{3}$ \\ ${ }^{1}$ Pendidikan Matematika, Universitas Islam Sultan Agung, Semarang, Indonesia; \\ *fairozanafiza@std.unissula.ac.id \\ 2Pendidikan Matematika, Universitas Islam Sultan Agung, Semarang, Indonesia; \\ hevyrisqi@unissula.ac.id \\ 3Pendidikan Matematika, Universitas Islam Sultan Agung, Semarang, Indonesia; \\ abdulbasir@unissula.ac.id
}

\begin{abstract}
Abstrak. Kemampuan berpikir kreatif yakni suatu kemampuan yang terdapat di siswa. Selain kemampuan berpikir kreatif terdapat juga kemampuan prestasi belajar siswa, serta kemampuan pemecahan masalah. Siswa mampu dikatakan kreatif jika mampu menyelesaikan soal secara berpikir kreatif yakni bagaimana dapat menemukan penyelesaian dengan berbagai ide serta berbagai jawaban. Berdasarkan hasil penelitian bahwa hasil kemampuan berpikir kreatif di SMA 1 Bae Kudus materi trigonometri bervariatif. Tujuan penelitian ini mengetahui tingkat kemampuan berpikir kreatif yang dimiliki siswa terhadap materi trigonometri. Penelitian ini mengacu dengan 3 indikator yakni indikator kefasihan, indikator fleksibilitas, serta indikator kebaruan. Jenis penelitian yaitu penelitian kualitatif. Objek penelitian yakni suatu topik yang terdapat dalam penelitian seperti berpikir kreatif siswa, bangunan menara kudus, materi trigonometri, tes kemampuan berpikir kreatif, pedoman wawancara. Sedangkan subjek penelitian yaitu 2 siswa dalam kemampuan matematika awal tinggi, 2 siswa di kemampuan matematika sedang, serta 2 siswa kategori kemampuan matematika rendah. Pemilihan 2 siswa pada masing-masing kategori karena dengan 2 siswa mampu mewakili dalam penelitian. Pengambilan subjek berdasarkan teknik purposive sampling. Sedangkan metode pengumpulan data dengaan tes kemampuan berpikir kreatif, serta wawancara. Teknik analisis data yaitu: (1) mereduksi data, (2) menyajikan data. (3) menarik kesimpulan. Kemudian hasil penelitian adalah siswa yang kemampuan matematika tinggi mempunyai tingkatan kemampuan sangat kreatif, siswa yang kemampuan matematika sedang pada tingkatan kreatif, sedangkan siswa yang kemampuan matematika rendah di tingkat kurang kreatif serta tidak kreatif. Siswa yang mempunyai perbedaan tingkatan kemampuan berpikir kreatif disebabkan oleh pengalaman belajar, dan motivasi belajar mereka yang berbeda.
\end{abstract}

Kata Kunci : Tingkat Kemampuan Berpikir Kreatif, Kemampuan Awal Matematika, Trigonometri. 
Abstract. Creative thinking ability is an ability that must be present in students. In addition to the ability to creative thinking, there are also student achievement ability, as well as problem solving ability. Creative thinking student share various education for how to find solutions with ideas and answers. The results of the creative thinking ability in SMA 1 Bae Kudus varied trigonometric material. The objectives of this study were to describe the level of student creative thinking skills trigonometric material. The purpose is to describe creative thinking ability levels of students to trigonometric material further. In this case the researcher uses indicator of fluency, flexibility, and novelty. This type of this research was a qualitative research. The subjects in this research were 2 students with high initial mathematics ability, 2 students with moderate initial mathematics ability, and 2 students with low initial mathematics ability. The choice of 2 students in each category is because 2 students are able to represent in the research. The subjects were taking based on purposive sampling technique. As for the data collection methods using tests of creative thinking ability and interviews. The data analysis technique in this study includes: (1) reduced data (2) presented of data (3) drawing conclusions. The results of this research were students in the category of high initial mathematics ability had creative thinking ability at level very creative, students with moderate initial mathematics ability had creative thinking ability at level creative, students with low initial mathematics ability had creative thinking ability at level less creative and not creative. So the differences in the level of creative thinking ability were caused by their different learning experiences and learning motivations.

Keywords: Level of Creative Thinking Ability, Initial Mathematics Ability, Trigonometry.

\section{Pendahuluan}

Matematika adalah pelajaran yang didapatkan mulai dari tingkat Sekolah Dasar (SD) hingga Perguruan Tinggi sedangkan untuk materi yang dipelajari mencakup simbol matematika dan perhitungan angka (Somawati, 2018). Sisk (dalam Machromah, Riyadi, \& Usodo, 2015) mengatakan secara umum pembelajaran matematika didukung dengan mengenal rumus serta konsep dengana cara verbal, namun tetap memerhatikan pemahaman siswa dalam pembelajaran matematika yang dirasakan belum mencapai dalam pengembangan pada daya nalar, logika, dan cara berpikir siswa. Siswa hanya mengikuti prosedur dari apa yang didapatkan di pembelajaran siswa cenderung tidak berusaha guna memecahkan alternatif yang relatif berbeda dalam menjawab masalah matematika. Sedangkan Basir (2015) mengatakan bahwa pembelajaran matematika akan terasa bermakna jika adanya kalobasi, interaksi diantara guru dengan siswa. 
Melalui belajar matematika siswa mampu dilatih secara berpikir kreatif, berpikir kritis serta mampu menerapkan matematika untuk memecahkan permasalahan pada kehidupan sehari-hari (Afizon, Ratnawulan, \& Fauzi, 2012; Dewanti, 2011). Oleh karena itu, dalam mempelajari matematika adanya hubungan antara pemecahan permasalahan dalam kehidupan sehari-hari dengan berpikir kreatif (Mufidah, 2014; Moma, 2015). Selain itu, Susanti (2016) mengatakan bahwa dalam mempelajari matematika perlu adanya berpikir kreatif untuk menyelesaikan permasalahan matematika. Hal ini sejalan dengan pandangan Fauziah, Sunardi, \& Kristiana (2016) kemampuan berpikir secara kreatif serta kemampuan memecahkan masalah dibutuhkan pada matematika. Selain untuk menyelesaikan permasalahan matematika ternyata berpikir kreatif juga sangat dibutuhkan di masa globalisasi seperti ini (Maharani, 2014).

Berdasarkan hasil pengamatan peneliti di lapangan bahwa siswa hanya mengikuti cara-cara yang paling mudah diajarkan oleh guru selama pembelajaran di kelas. Sehingga siswa dalam mengerjakan soal matematika sering menggunakan hanya cara-cara tertentu yang diajarkan guru. Selain itu, jarangnya guru memberikan soal yang mampu dikerjakan dengan berbagai cara hal ini kaitannya dengan berpikir kreatif. Sehingga siswa menganggap bahwa matematika hanya mampu dikerjakan dengan satu cara tertentu saja. Serta hasil wawancara guru dengan peneliti menyatakan dari hasil belajar siswa di kelas X MIPA 7 SMAN 1 Bae Kudus yang cukup rendah untuk materi trigonometri. Pada pembelajaran untuk materi trigonometri masih dikatakan sulit dalam memecahkan persoalan yang telah diberikan. Hasil wawancara menunjukkan faktor yang menyebabkan siswa mengalami kesulitan dalam memecahkan soal-soal trigonometri yakni materi trigonometri merupakan materi yang sulit untuk siswa jenjang SMA karena materinya sangat kompleks. Berikut adalah hasil belajar siswa untuk materi trigonometri.

Tabel 1. Hasil Belajar Siswa Materi Trigonometri

\begin{tabular}{clcc}
\hline No & & Inisial Siswa & Nilai \\
\hline 1 & AM & 53 \\
2 & LA & 60 \\
3 & MIP & 35 \\
4 & SM & 33 \\
5 & VMA & 60 \\
6 & WK & 75 \\
\hline
\end{tabular}


Guru sadar akan rendahnya hasil belajar siswa terhadap materi trigonometri maka diperlukan langkah lain untuk mempelajarinya yakni guru dapat menghubungkan pembelajaran dengan kehidupan sehari-hari. Salah satunya yaitu dapat matematika dengan bangunan menara kudus. Bangunan menara kudus ini dapat dihubungkan dengan berbagai materi matematika seperti: trigonometri, bangun datar, bangun ruang, dan sebagainya. Akan tetapi peneliti memilih materi trigonometri untuk mengukur bagaimana siswa mampu menentukan jarak dan sudut elevasi untuk mendapatkan tinggi bangunan menara kudus secara benar dengan berbagai cara atau berbagai jawaban. Selain itu, alasan peneliti memilih bangunan menara kudus karena belum adanya penelitian yang mengaitkan bangunan menara kudus. Tujuan dari penelitian ini adalah untuk mengetahui tingkat kemampuan berpikir kreatif siswa pada materi trigonometri. Berdasarkan latar belakang maka peneliti termotivasi melaksanakan penelitian dengan judul "Analisis Tingkat Kemampuan Berpikir Kreatif Materi Trigonometri".

\section{Metode Penelitian}

Jenis dari penelitian merupakan penelitian kualitatif. Pelaksanaan penelitian ini pada kelas X- MIPA 7 SMAN 1 Bae Kudus. Pemilihan subjek terdiri 6 siswa yang masing-masing terdiri dari 2 siswa untuk kemampuan matematika awal tinggi, sedang, rendah. Sedangkan objek yang diteliti adalah kemampuan berpikir kreatif yang siswa miliki serta hasil belajar siswa dalam kelas X MIPA 7 di SMAN 1 Bae Kudus terhadap materi trigonometri. Teknik pengambilan subjek penelitian ini dengan purposive sampling karena peneliti memiliki ciri-ciri khusus dalam pengambilan sampel. Pengumpulan data yang dilakukan terdiri dari dua cara yakni tes tertulis kemampuan berpikir kreatif dan wawancara. Tes tertulis menggunakan indikator kelancaran, fleksibilitas, serta kebaruan. Sedangkan untuk wawancara ini digunakan untuk mengetahui secara mendalam jawaban tes tertulis subjek penelitian. Teknik pada analisis data dengan melakukan reduksi, pemaparan, verifikasi serta penarikan kesimpulan. Reduksi adalah memilah data mana data yang harus digunakan atau tidak dalam penelitian. Pemaparan data adalah memaparkan data secara detail, serta verifikasi data adalah pengecekan data apakah data sudah benar atau belum.

Adapun pemilihan subjek ini didasarkan pada rekomendasi guru, hasil tes sebelumnya, serta siswa yang komunikatif. Kemampuan awal matematika siswa diperoleh dari nilai tes pada materi trigonometri khususnya pada materi

Copyright (C) 2020

Buana Matematika :

Jurnal Ilmiah Matematika dan Pendidikan Matematika 
nilai perbandingan trigonometri dalam sudut istimewa sebelum diterapkannya soal kemampuan berpikir kreatif. Pengelompokan kemampuan awal matematis (KAM) siswa berdasarkan nilai perhitungan rata-rata $\overline{(x)}$ serta simpangan baku (SB) yang diperoleh dari hasil tes sebelumnya.

Tabel 2. Kriteria Penggolongan Kemampuan Awal Matematis (KAM)

\begin{tabular}{ll}
\hline Kemampuan Awal Matematis & Kategori KAM \\
\hline $\mathrm{KAM} \geq \overline{\boldsymbol{x}}+\mathrm{SB}$ & Tinggi \\
$\overline{\boldsymbol{x}}-\mathrm{SB} \leq \mathrm{KAM}<\overline{\boldsymbol{x}}+\mathrm{SB}$ & Sedang \\
$\mathrm{KAM}<\overline{\boldsymbol{x}}-\mathrm{SB}$ & Rendah \\
\hline
\end{tabular}

Berdasarkan dari hasil kriteria pengelompokan kemampuan awal matematika maka didapatkan 6 subjek penelitian. Berikut subjek yang terpilih dalam penelitian ini adalah.

Tabel 3. Daftar Inisial Subjek Terpilih

\begin{tabular}{cccc}
\hline No & Inisial Siswa & Kode Siswa & Kemampuan Awal Matematika \\
\hline 1 & WK & $\mathrm{ST}_{1}$ & Tinggi \\
2 & $\mathrm{VMA}$ & $\mathrm{ST}_{2}$ & Tinggi \\
3 & $\mathrm{LA}$ & $\mathrm{SS}_{1}$ & Sedang \\
4 & $\mathrm{AM}$ & $\mathrm{SS}_{2}$ & Sedang \\
5 & $\mathrm{MIP}$ & $\mathrm{SR}_{1}$ & Rendah \\
6 & $\mathrm{SM}$ & $\mathrm{SR}_{2}$ & Rendah \\
\hline
\end{tabular}

\section{Hasil dan Pembahasan}

Peneliti dalam pengambilan data dilakukan dengan tes tertulis kemampuan berpikir kreatif serta wawancara untuk mendapatkan data yang valid mengenai tingkat kemampuan berpikir kreatif siswa. Tes tertulis serta wawancara yang diberikan perlu memerhatikan indikator kefasihan, fleksibilitas, serta kebaruan. Kefasihan yakni siswa bisa menghasilkan berbagai jawaban secara bernilai benar. Fleksibilitas merupakan siswa dapat membuat penyelesaian soal menggunakan berbagai cara. Sedangkan kebaruan yaitu siswa dapat menyelesaikan persoalan menggunakan cara unik yang jarang digunakan oleh siswa lainnya. Siswono (2008) mengklasifikasikan bahwa tingkat kemampuan berpikir kreatif terdiri dari 5 tingkatan yaitu tingkat 4 (sangat kreatif), tingkat 3 (kreatif), tingkat 2 (cukup kreatif), tingkat 1 (kurang kreatif), dan tingkat 0 (tidak kreatif). Berikut penjejangan tingkat kemampuan berpikir kreatif. 
Tabel 4. Penjejangan Tingkat Kemampuan Berpikir Kreatif

\begin{tabular}{ccccccccc}
\hline Indikator & Tingkat 4 & \multicolumn{2}{c}{ Tingkat 3 } & Tingkat 2 & Tingkat 1 & Tingkat 0 \\
\hline Kefasihan & $\sqrt{ }$ & $\sqrt{ }$ & $\sqrt{ }$ & - & - & - & $\sqrt{ }$ & - \\
Fleksibilitas & $\sqrt{ }$ & $\sqrt{ }$ & - & $\sqrt{ }$ & $\sqrt{ }$ & - & - & - \\
Kebaruan & $\sqrt{ }$ & - & $\sqrt{ }$ & $\sqrt{ }$ & - & $\sqrt{ }$ & - & - \\
\hline
\end{tabular}

Berdasarkan penjejangan tersebut maka terdapat 5 tingkatan. Dalam menentukan tingkat kemampuan berpikir kreatif tersebut terdapat beberapa indikator yang harus terpenuhi. Siswa dikatakan mempunyai tingkat 4 (sangat kreatif) jika siswa mampu memenuhi semua indikator baik kelancaran, fleksibilitas, serta kebaruan. Tingkat 3 (kreatif) jika siswa mampu memenuhi indikator kefasihan dan fleksibilitas atau kefasihan dan kebaruan atau memenuhi fleksibilitas dan kebaruan. Tingkat 2 (cukup kreatif) jika siswa mampu memenuhi indikator fleksibilitas atau kebaruan. Untuk tingkat 1 (kurang kreatif) jika siswa hanya memenuhi indikator kefasihan saja. Serta dalam tingkat 0 (tidak kreatif) siswa tidak mampu memenuhi semua indikator.

Setelah diperoleh hasil dari tes kemampuan berpikir secara kreatif selanjutnya pengkategorian sesuai tingkat kemampuan secara berpikir kreatif yang siswa miliki. Berikut hasil dari tes kemampuan berpikir secara kreatif siswa.

Tabel 5. Hasil Tes Tertulis Kemampuan Berpikir Kreatif

\begin{tabular}{|c|c|c|c|c|c|c|c|c|}
\hline \multirow[t]{2}{*}{ No } & \multirow{2}{*}{$\begin{array}{c}\text { Subjek } \\
\text { Penelitian }\end{array}$} & \multicolumn{3}{|c|}{ Soal Nomor 1} & \multicolumn{3}{|c|}{ Soal Nomor 2} & \multirow{2}{*}{$\begin{array}{l}\text { TKBK Subjek } \\
\text { Penelitian }\end{array}$} \\
\hline & & $\mathbf{a}$ & b & c & $\mathbf{a}$ & $\mathbf{b}$ & c & \\
\hline 1 & $\mathrm{ST}_{1}$ & $\sqrt{ }$ & $\sqrt{ }$ & $\sqrt{ }$ & $\sqrt{ }$ & $\sqrt{ }$ & $\sqrt{ }$ & $\begin{array}{l}\text { Tingkat } 4 \text { (sangat } \\
\text { kreatif) }\end{array}$ \\
\hline 2 & $\mathrm{ST}_{2}$ & $\sqrt{ }$ & $\sqrt{ }$ & - & $\sqrt{ }$ & $\sqrt{ }$ & - & Tingkat 3 (kreatif) \\
\hline 3 & $\mathrm{SS}_{1}$ & $\sqrt{ }$ & - & $\sqrt{ }$ & $\sqrt{ }$ & - & $\sqrt{ }$ & Tingkat 3 (kreatif) \\
\hline 4 & $\mathrm{SS}_{2}$ & $\sqrt{ }$ & $\sqrt{ }$ & - & $\sqrt{ }$ & $\sqrt{ }$ & - & Tingkat 3 (kreatif) \\
\hline 5 & $\mathrm{SR}_{1}$ & $\sqrt{ }$ & - & - & $\sqrt{ }$ & - & - & $\begin{array}{l}\text { Tingkat } 1 \text { (kurang } \\
\text { kreatif) }\end{array}$ \\
\hline 6 & $\mathrm{SR}_{2}$ & - & - & - & - & - & - & 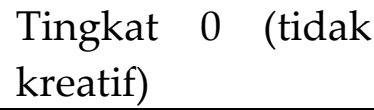 \\
\hline
\end{tabular}

Keterangan:

$$
\begin{aligned}
& \mathrm{ST}_{1}=\text { Siswa KAM tinggi } \\
& \mathrm{ST}_{2}=\text { Siswa KAM tinggi } \\
& \mathrm{SS}_{1}=\text { Siswa KAM sedang }
\end{aligned}
$$

Copyright (c) 2020

\section{Buana Matematika :}

Jurnal Ilmiah Matematika dan Pendidikan Matematika 


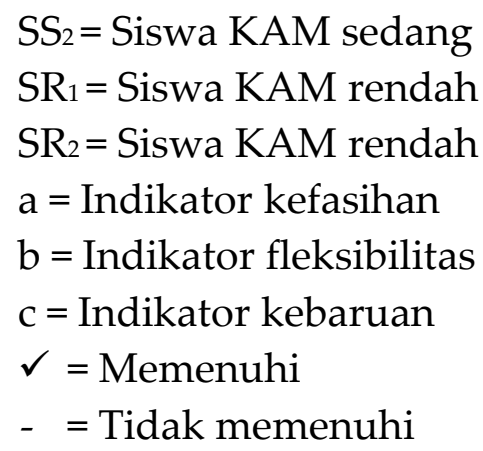

\section{Kemampuan Awal Matematika Tinggi}

Tabel 4 untuk subjek $\mathrm{ST}_{1}$ dan $\mathrm{ST}_{2}$ mempunyai kemampuan matematika tinggi. Berikut hasil jawaban siswa dalam kategori kemampuan matematika tinggi.

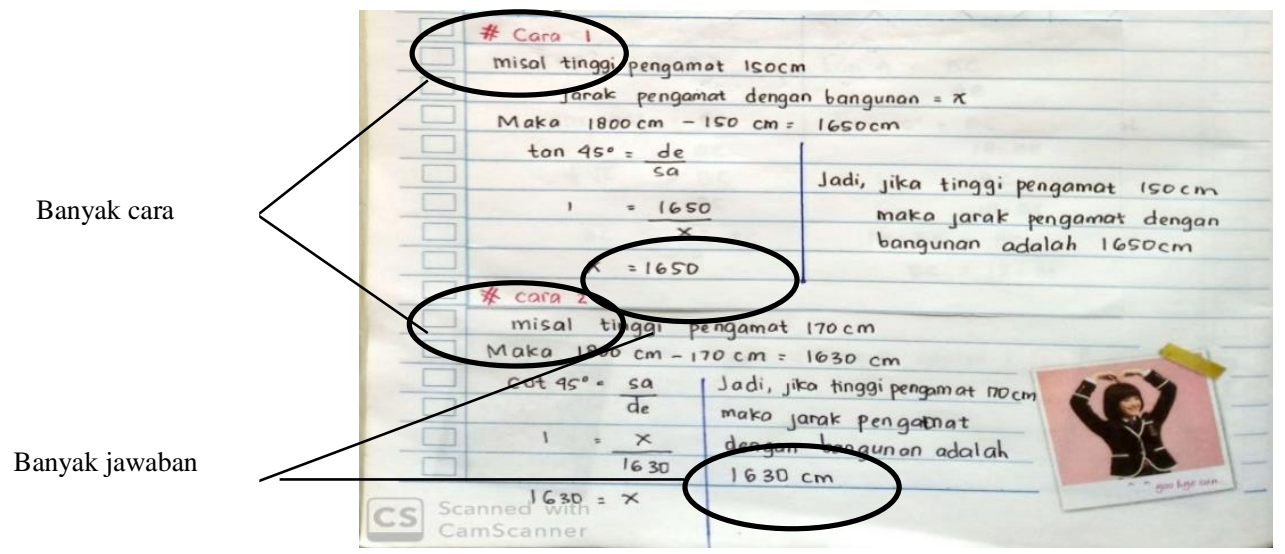

Gambar 1. ST 1 Soal Nomor 1 memenuhi kefasihan dan fleksibilitas

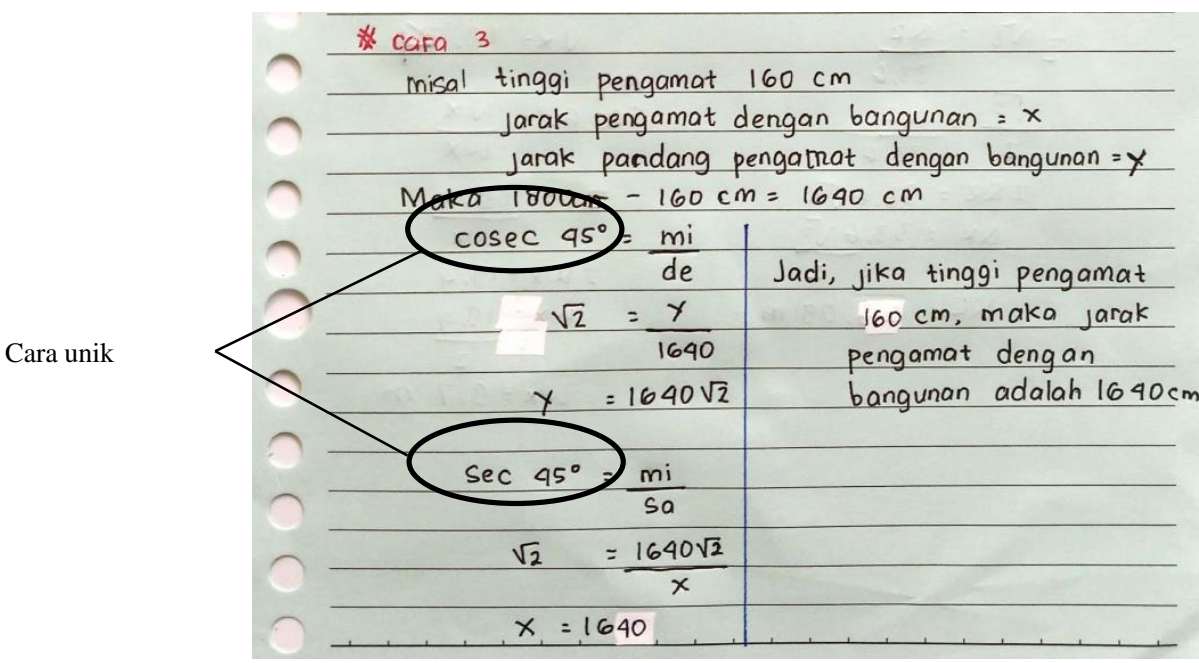

Gambar 2. $\mathrm{ST}_{1}$ Soal nomor 1 memenuhi kebaruan 


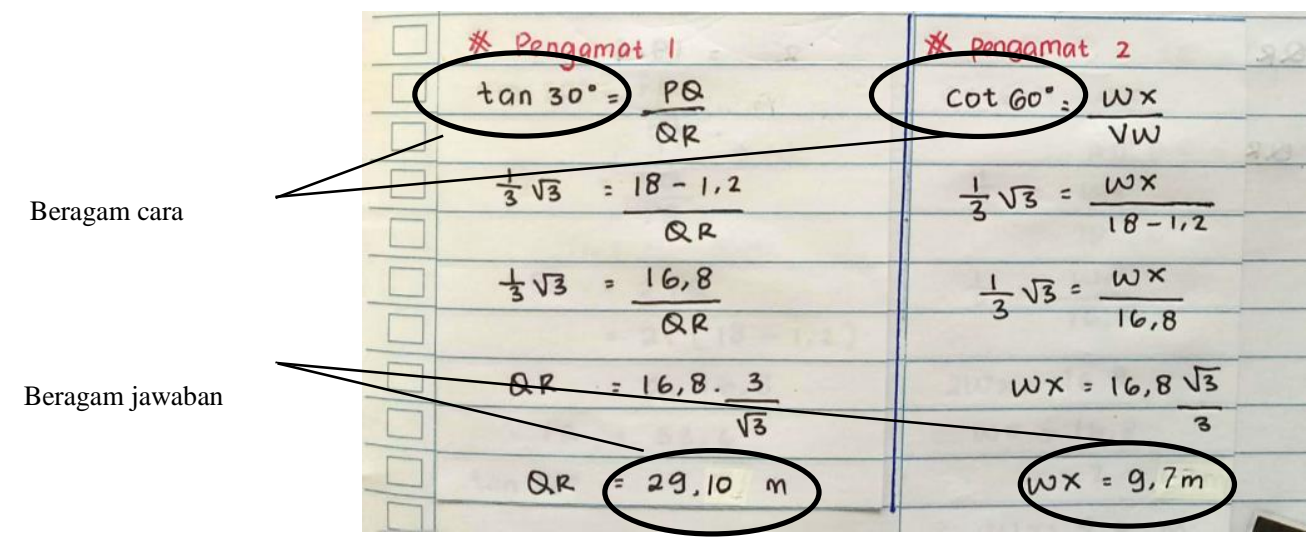

Gambar 3. $\mathrm{ST}_{1}$ Soal nomor 2 memenuhi kefasihan dan fleksibilitas

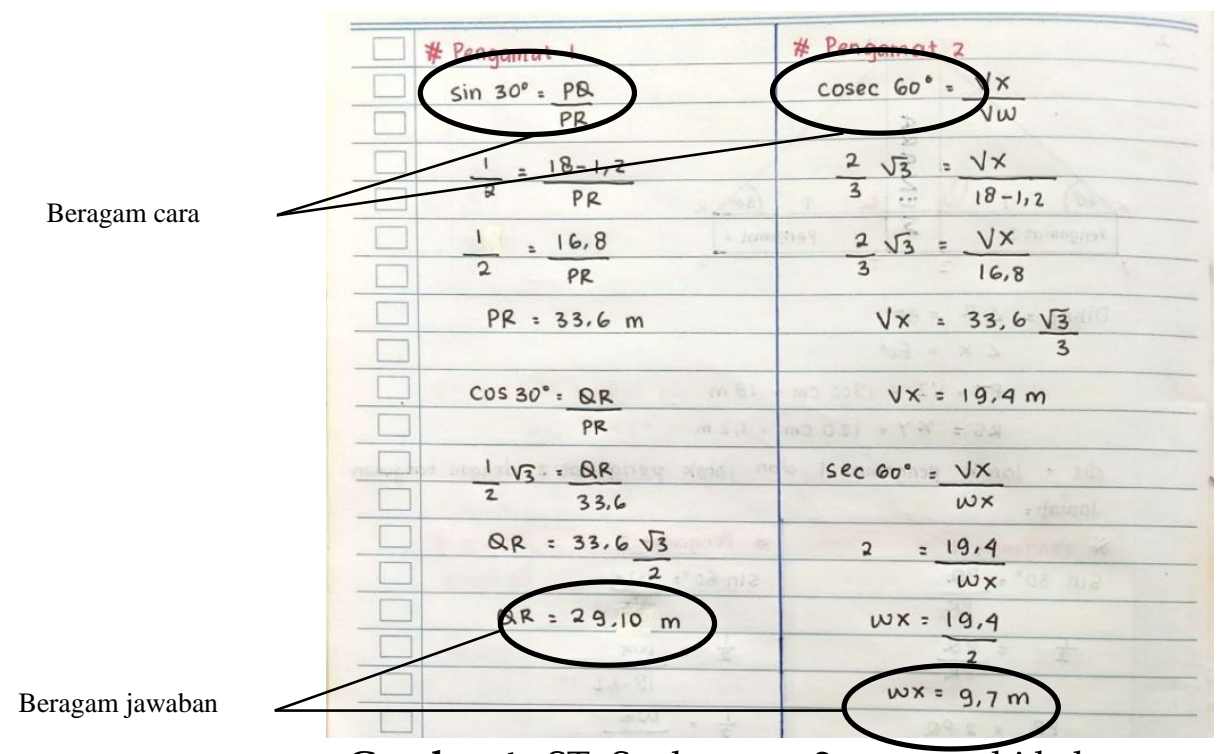

Gambar 4. $\mathrm{ST}_{1}$ Soal nomor 2 memenuhi kebaruan

Gambar 1 dan 3 dikatakan ST1 mampu memenuhi indikator kefasihan, fleksibilitas, sedangkan gambar 2 dan $4 \mathrm{ST}_{1}$ mampu memenuhi indikator kebaruan. Pada soal nomor 1 maupun nomor $2 \mathrm{ST}_{1}$ mampu memenuhi semua indikator. Oleh Karena $\mathrm{ST}_{1}$ di tingkat kemampuan berpikir kreatif pada tingkat 4 (sangat kreatif). Sedangkan $\mathrm{ST}_{2}$ berada ditingkat kemampuan berpikir secara kreatif di tingkatan 3 (kreatif). Hal ini dikarenakan $\mathrm{ST}_{2}$ hanya mampu memenuhi indikator kefasihan dan fleksibilitas untuk kedua soal. Sedangkan untuk indikator kebaruan ST 2 tidak memenuhi. Meskipun ST 1 dan $\mathrm{ST}_{2}$ mempunyai kemampuan matematika yang sama akan tetapi mereka berada dalam tingkat kemampuan berpikir kreatif yang berbeda.

Syam (2020) mengatakan bahwa siswa dengan kemampuan awal matematika tinggi mampu menemukan jawaban menggunakan jawaban serta caranya

Copyright (C) 2020

\section{Buana Matematika :}

Jurnal Ilmiah Matematika dan Pendidikan Matematika 
sendiri dengan proses perhitungan yang benar serta mampu memahami apa yang diinginkan terhadap soal. Siswa mampu mengetahui konsep-konsep matematika sehingga mampu menyelesaikan soal menggunakan berbagai cara dan jawaban. Sehingga siswa dengan kemampuan awal matematika tinggi untuk indikator kefasihan, dan fleksibilitas dikatakan sangat baik sedangkan indikator kebaruan dikatakan baik.

Hal ini sejalan dengan pendapat Samsiyah et al (2014) yang menyatakan siswa dengan kemampuan berpikir kreatif kategori tinggi untuk indikator kelancaran sangat baik disebabkan karena siswa dengan kategori tinggi bisa menghasilkan lebih dari satu jawaban dalam memecahkan masalah matematika maka untuk indikator kelancaran tidak mengalami kesuitan. Indikator fleksibilitas siswa dengan kategori matematika tinggi berada ditingkat baik karena mampu menghasilkan cara yang beragam. Sedangkan pada indikator kebaruan di tingkat baik karena siswa cara yang unik yang tidak umum dalam menyelesaikan permasalahan.

Pendapat ini sejalan dengan Komala (2017) menyatakan meskipun berada dalam kemampuan sama (kemampuan matematika awal tinggi) namun mempunyai tingkatan kemampuan berpikir kreatif yang tidak sama. Adanya perbedaan tersebut dipengaruhi oleh sikap tekun, pantang menyerah, motivasi belajar, serta berani mencoba ide-ide baru. Samsiyah, N., \& Rudyanto (2015) yang menyatakan siswa yang kemampuan berpikir secara kreatif dalam kategori tinggi pada indikator kelancaran dikatakan sangat baik. Hal ini disebabkan siswa dengan kategori tinggi mampu menghasilkan jawaban secara beragam, pada indikator fleksibilitas dikatakan sangat baik karena tidak mengalami kesulitan, sedangkan pada indikator kebaruan dikatakan baik karena terdapat siswa menggunakan ide secara general tetapi tetap merujuk ke pemecahannya. Saefrudin (2011) mengatakan siswa yang kemampuan matematika tinggi mempunyai tingkat kemampuan berpikir kreatif secara baik dalam menyelesaikan permasalahan matematika terbuka.

\section{Kemampuan Awal Matematika Sedang}

Tabel 4 untuk subjek $\mathrm{SS}_{1}$ dan $\mathrm{SS}_{2}$ mempunyai kemampuan matematika sedang. Berikut hasil jawaban siswa dalam kategori kemampuan matematika sedang. 


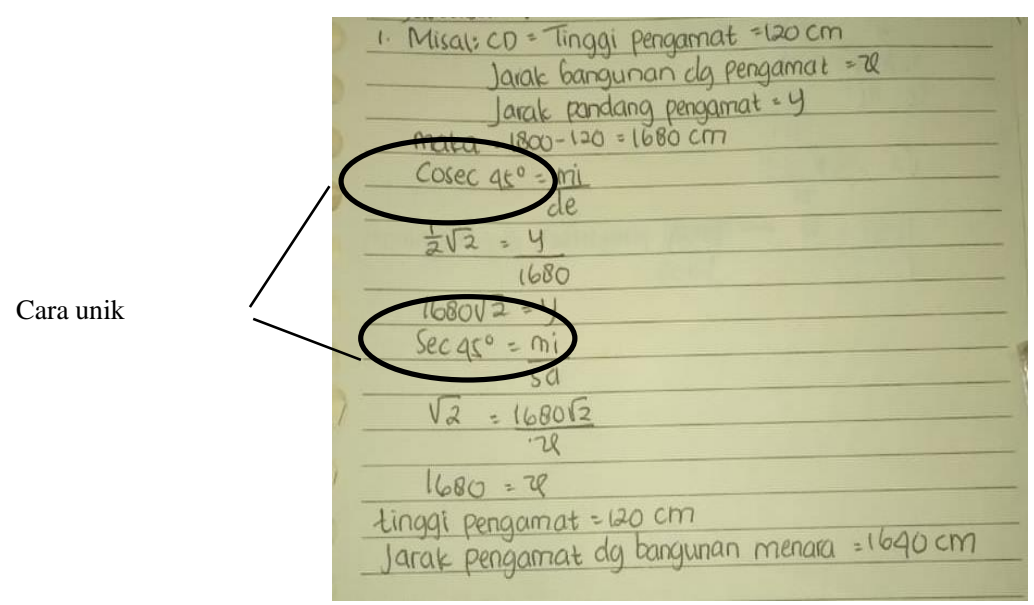

Gambar 5. SS 1 Soal nomor 1 memenuhi kebaruan

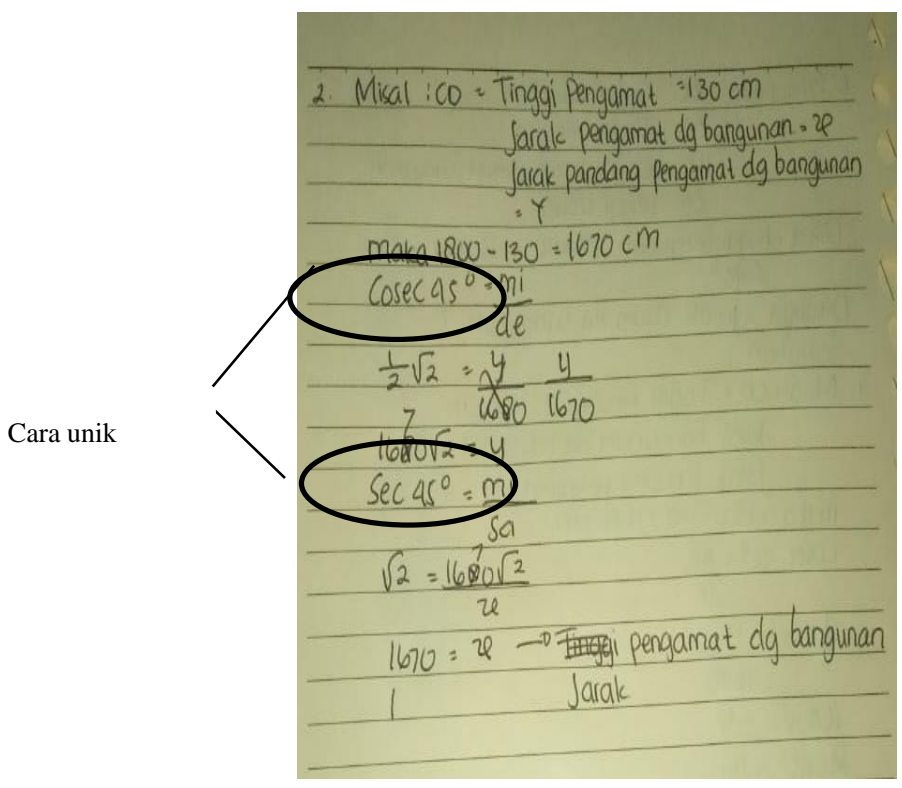

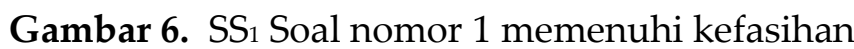

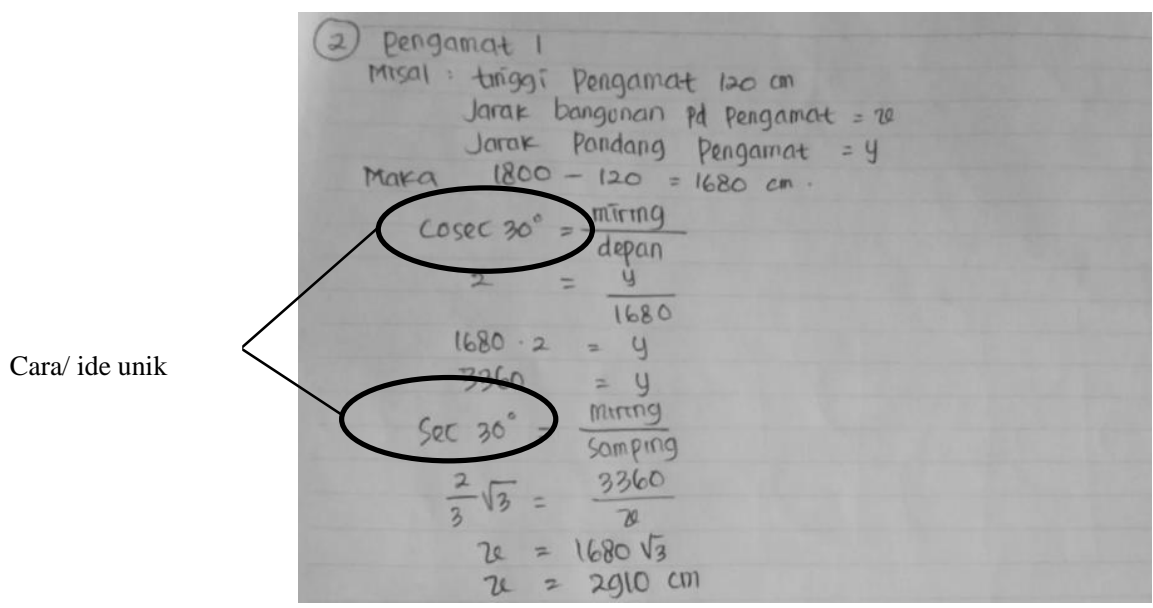

Copyright $@ 2020$

Buana Matematika :

Jurnal Ilmiah Matematika dan Pendidikan Matematika 
Gambar 7. SS $S_{1}$ Soal nomor 2 memenuhi kebaruan

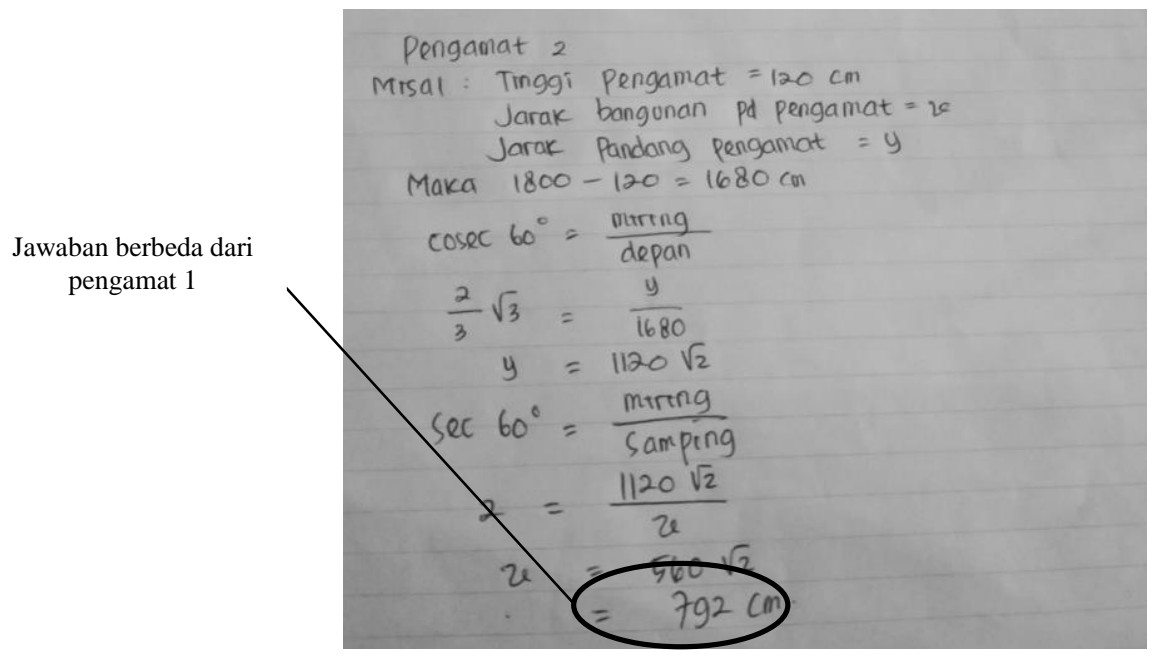

Gambar 8. SS S $_{1}$ Soal nomor 2 memenuhi kefasihan

Gambar 5 dan 7 menunjukkan bahwa SS $_{1}$ mampu memenuhi indikator kebaruan untuk kedua soal. Karena baik untuk soal nomor 1 dan 2 SS $_{1}$ mampu menghasilkan cara yang unik yang jarang digunakan oleh siswa lainnya. cara tersebut dikatakan unik karena nilai sudutnya berbentuk akar sehingga siswa jarang menggunakan cara tersebut dan siswa mengganggap cara tersebut merupakan cara yang sulit. Sedangkan pada gambar 6 dan 8 SS 1 mampu memenuhi indikator kefasihan karena SS1 mampu menghasilkan berbagai jawaban. SS 1 dikatakan tidak memenuhi indikator fleksibilitas karena SS $_{1}$ tidak mampu menghasilkan berbagai cara. $S_{1}$ hanya mampu menggunakan satu cara namun dengan satu cara tersebut mampu menghasilkan berbagai jawaban. Oleh karena itu, $\mathrm{SS}_{1}$ berada dalam tingkat kemampuan berpikir kreatif pada tingkat 3 (kreatif).

Sedangkan $\mathrm{SS}_{2}$ untuk kedua soal mampu memenuhi indikator kefasihan dan fleksibilitas. Hal ini disebabkan karena SS2 mampu menghasilkan berbagai cara dan berbagai jawaban. $\mathrm{SS}_{2}$ tidak mampu mengahasilkan cara yang unik yang jarang digunakan oleh siswa lainnya maka $\mathrm{SS}_{2}$ dikatakan tidak memenuhi indikator kebaruan. Karena $\mathrm{SS}_{2}$ hanya memenuhi indikator kefasihan dan juga fleksibilitas maka $\mathrm{SS}_{2}$ di tingkat kemampuan berpikir kreatif dalam tingkat 3 (kreatif).

Hal tersebut sama dengan pendapat dari Siswono (2008) mengatakan bahwa jika siswa mampu memenuhi indikator kefasihan serta fleksibilitas, kefasihan dan kebaruan, fleksibilitas dan kebaruan maka siswa tersebut berada di tingkat kemampuan berpikir kreatif di tingkat 3 (kreatif). Samsiyah, \& Copyright (C) 2020

\section{Buana Matematika :}

Jurnal Ilmiah Matematika dan Pendidikan Matematika 
Rudyanto (2015) mengatakan bahwa siswa dengan kemampuan matematika sedang untuk indikator kefasihan dan fleksibilitas dikatakan sangat baik. Sedangkan untuk indikator kebaruan dikatakan baik. Hal ini disebabkan karena siswa dengan kemampuan matematika sedang mampu menghasilkan berbagai cara serta berbaga jawaban tetapi belum pasti mampu menghasilkan cara yang unik yang berbeda dari siswa lainnya.

\section{Kemampuan Awal Matematika Rendah}

Tabel 4 untuk subjek $\mathrm{SR}_{1}$ dan $\mathrm{SR}_{2}$ mempunyai kemampuan matematika rendah. Berikut hasil jawaban siswa dalam kategori kemampuan matematika rendah.

Berbagai jawaban

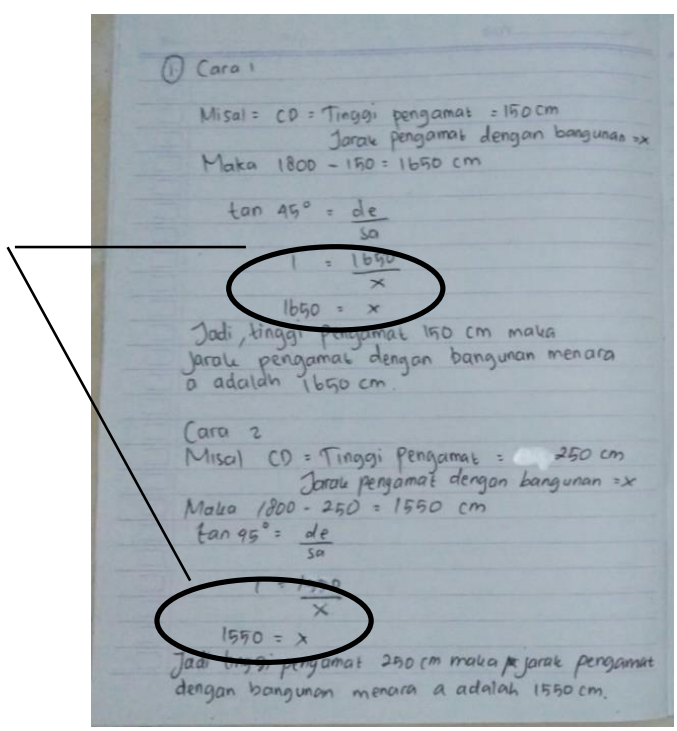

Gambar 9. SS1 Soal nomor 1 memenuhi kefasihan

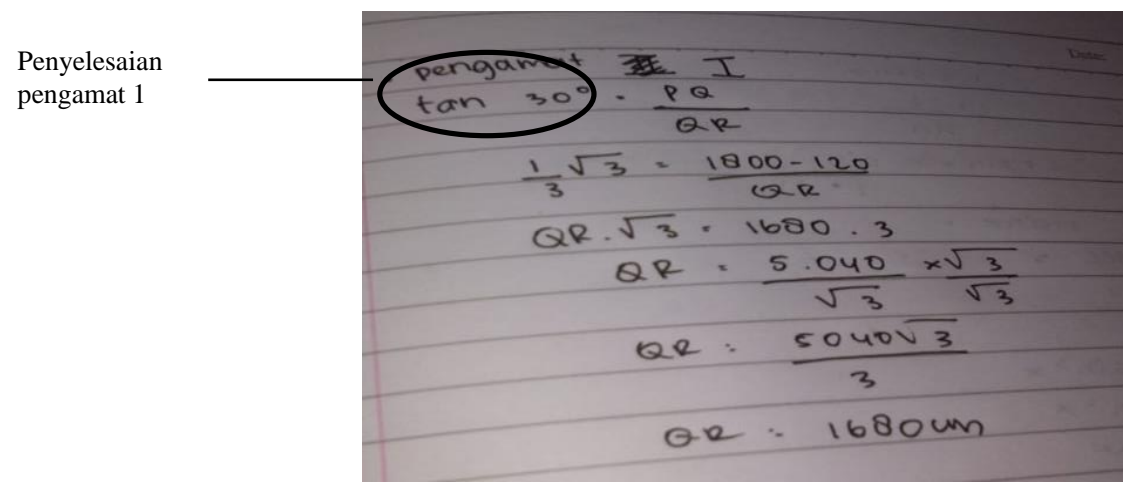

Gambar 10. $\mathrm{SS}_{1}$ Soal nomor 2 pengamat 1

Copyright (C) 2020

Buana Matematika :

Jurnal Ilmiah Matematika dan Pendidikan Matematika 


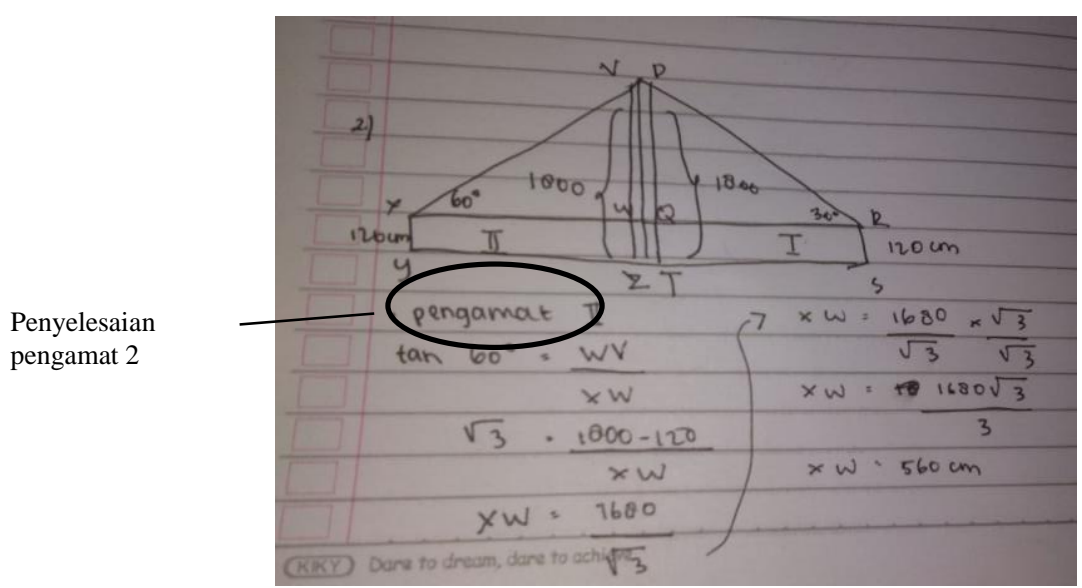

Gambar 11. SS 1 Soal nomor 2 pengamat 2

$\mathrm{SR}_{1}$ hanya mampu memenuhi indikator kefasihan saja. Hal tersebut terlihat di gambar 9 menunjukka soal di nomor $1 \mathrm{SR}_{1}$ menggunakan satu cara saja serta cara tersebut merupakan cara yang umum yang sering digunakan oleh siswa lainnya. Akan tetapi dari cara tersebut $\mathrm{SR}_{1}$ mampu menghasilkan berbagai jawaban maka $\mathrm{SR}_{1}$ tidak mampu memenuhi indikator fleksibilitas dan kebaruan. Hal ini juga berlaku untuk soal nomor 2 yang mana SR 1 juga mampu memenuhi indikator kefasihan saja. Berdasarkan hal tersebut maka $\mathrm{SR}_{1}$ hanya memenuhi indikator kefasihan saja maka dikatakan bahawa SR termasuk dalam tingkat kemampuan berpikir kreatif dalam tingkat 1 (kurang kreatif).

Hal ini berbeda dengan SR2 yang mana SR2 termasuk ke tingkat kemampuan berpikir kreatif dalam tingkat 0 (tidak kreatif). karena SR2 tidak dapat memenuhi semua indikator baik kefasihan, fleksibilitas, dan kebaruan untuk kedua soal. Maka meskipun SR1 dan SR2 mempunyai kemampuan awal matematika yang sama namun mereka memiliki tingkat kemampuan berpikir kreatif yang berbeda.

Samsiyah, \& Rudyanto (2015) menyatakan bahwa siswa dengan kemampuan matematika rendah untuk indikator kefasihan dikatakan sangat baik. Sedangkan untuk indikator fleksibilitas dan kebaruan dikatakan baik. Faelasofi (2017) mengatakan siswa dengan tingkat kemampuan kurang kreatif dan tidak kreatif cenderung menjawab dengan jawaban yang apa adanya tanpa adanya kesesuaian konteks materi. Bahkan terdapat beberapa siswa yang sama sekali belum mampu memecakan soal secara baik. Sintya, Purwanto, \& Sakti (2018) yang menjelaskan siswa kurang mampu dalam memecahkan persoalan matematika sehingga tidak memenuhi indikator kebaruan hal ini disebabkan karena siswa tidak terbiasa dalam memecahkan soal matematika dengan cara yang unik yang berbeda dari siswa lainnya. Nur Copyright (c) 2020

\section{Buana Matematika :}

Jurnal Ilmiah Matematika dan Pendidikan Matematika 
(2016) melakukan penelitian yang menjalaskan bahwa hasil dari tes kemampuan berpikir kreatif yang siswa miliki belum maksimal karena tidak semua siswa dikelas mampu membuka diri. Ada siswa malas untuk berpikir, mencari cara lain terhadap permasalahan yang diberikan. Serta siswa tidak terbiasa untuk mencari sendiri penyelesaian masalah dengan cara atau jawaban yang berbeda dari siswa lainnya. Hal ini sejalan dengan hasil tes kemampuan berpikir kreatif dari SR2.

\section{Simpulan}

Penjejangan tingkat kemampuan berpikir kreatif terbagi 5 tingkatan yaitu tingkat 4 (sangat kreatif), tingkat 3 (kreatif), tingkat 2 (cukup kreatif), tingkat 1 (tidak kreatif), serta tingkat 0 (tidak kreatif). Setelah terpilihnya subjek penelitian yang terdiri masing-masing 2 siswa dalam kemampuan awal matematika tinggi, sedang, rendah berdasarkan kemampuan awal matematika siswa, hasil tes sebelumnya, serta siswa yang komunikatif. Pemberian soal tes tertulis dan wawancara ini dilakukan untuk mengetahui tingkat kemampuan berpikir kreatif siswa pada materi trigonometri. Berdasarkan hasil tes tertulis dan wawancara maka didapatkan hasil bahwa siswa yang kemampuan matematika tinggi berada dalam tingkat kemampuan berpikir kreatif sangat kreatif dan kreatif. Siswa dengan kemampuan matematika tinggi mampu memenuhi indikator semua indikator atau mampu memenuhi indikator kefasihan dan fleksibilitas. Sedangkan siswa dengan kemampuan matematika sedang berada dalam tingkat kemampuan berpikir secara kreatif pada tingkatan kreatif. Hal ini terbukti karena siswa dengan kemampuan matematika sedang mampu memenuhi indicator kefasihan dan kebaruan atau kefasihan dan fleksibilitas. Serta siswa yang mempunyai kemampuan berpikir kreatif rendah mampu berada dalam tingkat kemampuan berpikir kreatif pada tingkat kurang kreatif bahkan ada yang tidak kreatif. Karena hanya memenuhi indicator kefasihan saja bahkan ada siswa yang tidak mampu memenuhi semua indikator. Adanya perbedaan tingkat kemampuan berpikir kreatif yang siswa miliki tergantung dari sikap tekun siswa, motivasi belajar siswa, serta pengalaman belajar siswa yang berbeda pula. Penelitian ini digunakan sebagai referensi lebih lanjut dalam mengetahui tingkat kemampuan berpikir kreatif di materi trigonometri sehingga memperoleh tingkatan secara optimal. 


\section{Daftar Pustaka}

Afizon, R., Ratnawulan, R., \& Fauzi, A. (2012). Peningkatan perilaku berkarakter dan keterampilan berpikir kritis siswa Kelas IX MTsN Model Padang pada mata pelajaran IPA-fisika menggunakan model problem based instruction. Jurnal Penelitian Pembelajaran Fisika, 1(1), 1-16.

Basir, M. A. (2015). Pengembangan Bahan Ajar Trigonometri Melalui Model Search, Solve, Create, and Share untuk Meningkatkan Kemampuan Penalaran. SEMINAR NASIONAL MATEMATIKA DAN PENDIDIKAN MATEMATIKA UNY 201.

Dewanti, S. S. (2011). Mengembangkan Kemampuan Berpikir Kritis Mahasiswa Pendidikan Matematika Sebagai Calon Pendidik Karakter Bangsa Melalui Pemecahan Masalah. Prosiding Seminar Nasional Matematika Universitas Muhammadiyah Surakarta, 29-37.

Faelasofi, R. (2017). Identifikasi Kemampuan Berpikir Kreatif Matematika Pokok Bahasan Peluang. 3(2), 155-163.

Fauziah, E. W., Sunardi, S., \& Kristiana, A. I. (2016). Analisis Tingkat Berpikir Kreatif Dalam Pengajuan Masalah Matematika Pokok Bahasan Bangun Ruang Sisi Datar Berdasarkan Gaya Kognitif Reflektif-Impulsif Siswa Kelas VIII-F SMP Negeri 12 Jember. Jurnal Edukasi, 2(2), 1-6.

Komala, E. (2017). M ATHEMATICAL R ESILIENCE M AHASISWA PADA $M$ ATA K ULIAH S TRUKTUR A LJABAR I M ENGGUNAKAN P ENDEKATAN E XPLISIT. Jurnal "Mosharafa," 6(3), 357-364.

Machromah, I. U., Riyadi, R., \& Usodo, B. (2015). Analisis Proses Dan Tingkat Berpikir Kreatif Siswa SMP Dalam Pemecahan Masalah Bentuk Soal Cerita Materi Lingkaran Ditinjau Dari Kecemasan Matematika. Jurnal Pembelajaran Matematika, 3(6), 613-624.

Maharani, H. R. (2014). CREATIVE THINKING IN MATHEMATICS : ARE WE ABLE TO SOLVE MATHEMATICAL PROBLEMS IN A VARIETY OF WAY. International Conference on Mathematics, Science, and Education, 120125.

Moma, L. (2015). Pengembangan Instrumen Kemampuan Berpikir Kreatif Matematis Untuk Siswa SMP. Delta-Pi: Journal Matematika Dan Pendidikan Matematika, 4(1), 27-41.

Mufidah, I. (2014). IDENTIFIKASI KEMAMPUAN BERPIKIR KREATIF SISWA DALAM PEMECAHAN MASALAH MATEMATIKA MATERI SEGIEMPAT DAN SEGITIGA DITINJAU DARI KEMAMPUAN MATEMATIKA SISWA DI KELAS VII SMPN 1 DRIYOREJO. MATHEdunesa, 3(2), 113-119.

Nur, I. R. . (2016). MENINGKATKAN KEMAMPUAN BERPIKIR KREATIF

Copyright (C) 2020

Buana Matematika :

Jurnal Ilmiah Matematika dan Pendidikan Matematika 


\section{MATEMATIS DAN KEMANDIRIAN BELAJAR SISWA DENGAN} MENGGUNAKAN MODEL PEMBELAJARAN BRAIN BASED LEARNING. Jurnal Pendidikan Unsika, 4(1), 26-41.

Saefrudin, A. A. (2011). Proses Berpikir Kreatif Siswa Sekolah Dasar (SD)

Berkemampuan Matematika Tinggi Dalam Pemecahan Masalah Matematika Terbuka. Pendidikan Matematika FMIPA UNY, 1-4.

Samsiyah, N., \& Rudyanto, H. E. (2015). Kemampuan Berpikir Kreatif Dalam

Memecahkan Masalah Matetatika Open-Ended Ditinjau Dari Tingkat

Kemampuan Matematika Siswa Sekolah Dasar. PEDAGOGIA: Jurnal Pendidikan, 4(1), 23. https://doi.org/10.21070/pedagogia.v4i1.69

Sintya, W. K., Purwanto, A., \& Sakti, I. (2018). Penerapan Model Pembelajaran Inkuiri Terbimbing Untuk Meningkatkan Kemampuan Berpikir Kreatif Siswa di SMAN 2 Kota Bengkulu. Jurnal Kumparan Fisika, 1(3), 7-12.

Siswono, T. Y. E. (2008). Model pembelajaran matematika berbasis pengajuan dan pemecahan masalah untuk meningkatkan kemampuan berpikir kreatif.

Somawati, S. (2018). Peran Efikasi Diri (Self Efficacy) terhadap Kemampuan Pemecahan Masalah Matematika. Jurnal Konseling Dan Pendidikan, 6(1), 39. https://doi.org/10.29210/118800.

Susanti, D. (2016). Profil Berpikir Kreatif Dalam Menyelesaikan Soal Cerita Matematika. Buana Matematika: Jurnal Ilmiah Matematika Dan Pendidikan Matematika, 6(2:), 15-24.

Syam, A. S. M. (2020). Analisis kemampuan berpikir kritis dan kreatif dalam pemecahan masalah matematika berdasarkan kemampuan matematika siswa. Ekspose: Jurnal Penelitian Hukum dan Pendidikan, 19(1), 939-946.

\section{Riwayat Hidup Penulis}

\section{Narita Fifi Zulaikha}

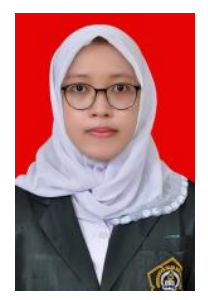

Lahir di Kudus, 18 Desember 1997. Studi S1 Pendidikan Matematika Universitas Islam Sultan Agung Semarang dan lulus pada tahun 2020. 


\section{Hevy Risqi Maharani}

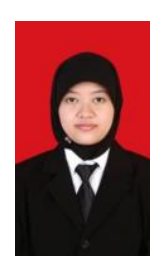

Lahir di Semarang, 10 Agustus 1987. Staf pengajar di Universitas Islam Sultan Agung Semarang. Studi S1 Pendidikan Matematika Universitas Negeri Semarang, lulus tahun 2009; S2 Pendidikan Matematika Universitas Islam Sultan Agung Semarang, lulus tahun 2012; dan sekarang masih melanjutkan S3 Pendidikan Matematika Universitas Negeri Semarang.

\section{Mochamad Abdul Basir}

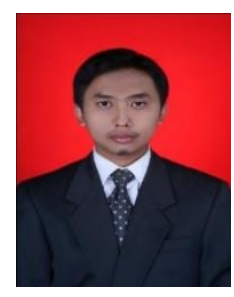

Lahir di Kota Semarang, 08 Oktober 1983. Staf pengajar di Universitas Islam Sultan Agung Semarang. Studi S1 Pendidikan Matematika Universitas Negeri Semarang, lulus tahun 2006; S2 Pendidikan Matematika Universitas Negeri Semarang, lulus tahun 2012; dan sekarang masih melanjutkan S3 Pendidikan Matematika Universitas Negeri Semarang. Penulis tertarik pada penelitian bidang psikologi kognitif dan pengembaangan bahan ajar di bidang Aljabar dan Kalkulus. 
Jurnal Ilmiah Matematika dan Pendidikan Matematika Vol. 10 No. 2 (2020)

Copyright $(92020$

Buana Matematika :

Jurnal Ilmiah Matematika dan Pendidikan Matematika 